\title{
Effect of photoinhibition during bottle incubations on the measurement of seasonal primary production in a shallow coastal water*
}

\author{
Joel C. Goldman and Mark R. Dennett
}

Woods Hole Oceanographic Institution, Woods Hole, Massachusetts 02543, USA

\begin{abstract}
Primary productivity in Vineyard Sound, Massachusetts (USA), a shallow well-mixed coastal water, was determined at monthly intervals during May-October, 1981. Over the course of each study day fresh samples first were obtained at $3 \mathrm{~h}$ intervals and then incubated until sunset with timecourse measurements of $\mathrm{H}^{14} \mathrm{CO}_{3}^{-}$uptake made at frequent intervals. Two seasonal patterns of ${ }^{14} \mathrm{C}$ uptake were apparent. First, rapid initial uptake of ${ }^{14} \mathrm{C}$ over each incubation during the spring and fall was followed by reduced uptake during periods of strong sunlight. The duration over which rapid uptake was sustained was a function of the prevailing light intensity at the start of the incubation. Under these conditions estimates of near surface primary productivity based on summing total production over the first $3 \mathrm{~h}$ of each back to back incubation were higher by 50 to $130 \%$ than estimates based on single end-point measurements from full-day incubations. During summer, however, uptake of ${ }^{14} \mathrm{C}$ was linear throughout each incubation when both total daily irradiation and temperature were maximal so that the 2 techniques for estimating productivity led to comparable results. The reasons for these seasonal differences in the pattern of ${ }^{14} \mathrm{C}$ uptake are unclear, but may be related to changes in temperature or phytoplankton species, or both. Our results for a shallow well-mixed water are in general accord with the conclusion of Harris (1980) that when vertical mixing is sufficient to prevent prolonged exposure of phytoplankton to photoinhibiting light intensities at the surface, photoinhibition could be far more pronounced during a bottle incubation than is occurring in the water column.
\end{abstract}

\section{INTRODUCTION}

Utility of the ${ }^{14} \mathrm{C}$ bottle incubation technique for measuring marine primary productivity is based, to a large extent, on the premise that biological activity in a confined and small (hundreds of ml) sample of water under a light regime representative of the depth from where the sample was obtained and over incubation periods extending up to tens of hours will be comparable to what would have occurred had the sample been left undisturbed in the water column. In recent years, however, evidence has been accumulating that, for a variety of reasons, the longer a sample is confined the more pronounced may be the deviation between true water column primary productivity and the measured bottle rate (Harris, 1980; Goldman et al., 1981).

One of the major concerns with long incubations is

- Contribution No. 5437 from the Woods Hole Oceanographic Institution that photoinhibition, which commonly is observed in surface samples exposed to correspondingly high irradiation, may be far more pronounced in the incubation bottle than actually is taking place in the water column, thereby leading to underestimates of true primary productivity (Harris, 1980). The major problem is that photoinhibition is a time-dependent process (Kok, 1956; Takahashi et al., 1971) so that, depending on the prevailing patterns of vertical water movements, cells in the water column may have a significantly different temporal history of exposure to inhibiting irradiation than when confined in a bottle (Harris and Lott, 1973; Harris and Piccinin, 1977; Marra, $1978 \mathrm{a}$, b). It is not surprising, therefore, that higher rates of photosynthesis have been observed on numerous occasions when cells were exposed to fluctuating rather than constant irradiation (Jewson and Wood, 1975; Jones, 1978; Marra, 1978a, b; Savidge, 1980; Gallegos et al., 1980; Gallegos and Platt, 1982), when short-term rates were compared with longer-term rates 
under greater than saturating levels of irradiation (Ichimura and Saijo, 1958; Barnett and Hirota, 1967 ; Harris and Lott, 1973; Harris and Piccinin, 1977), or when the summed production from back to back incubations of short duration involving fresh samples taken over the course of a day were compared with production from a single incubation representing the same total time interval as the back to back incubations (Rodhe, 1958; Vollenweider and Nauwerck, 1961; Hammer et al., 1973; Gieskes et al, 1979).

In the present study we performed a series of back to back ${ }^{14} \mathrm{C}$ incubations, each involving time-course measurements of primary productivity of fresh samples from a shallow location in Vineyard Sound, Massachusetts, midway between Martha's Vineyard and Woods Hole. We carried out these studies at monthly intervals over a 6 mo period to assess both the daily and seasonal interactions of sunlight and temperature upon the measurement of primary production.

\section{METHODS}

\section{Primary production measurements}

On each of the 6 study days between May 14, 1981 and October 29, 1981 we collected a series of samples at approximately $3 \mathrm{~h}$ intervals from pre-dawn until late afternoon (Table 1). Each sample was collected from $1 \mathrm{~m}$ depth with a 61 Niskin bottle, filtered through 202 um Nitex mesh, and returned to the Woods Hole Oceanographic Institution (WHOI) where the incubations were performed outdoors. We incubated each sample for the balance of the day and made timecourse measurements of $\mathrm{H}^{14} \mathrm{CO}_{3}^{-}$incorporation into organic matter. Our incubation system, consisting of ten 11 vessels, was identical to the one use previously in other Vineyard Sound studies (Goldman et al., 1981;
Glibert et al., 1982). Each vessel was held at ambient temperature by circulating water from a temperaturecontrolled bath and was mixed continuously by magnetic bar stirring. Irradiation incident to each vessel was regulated at $60 \%$ of full sunlight $\left(I_{0}\right)$ with neutral density screens.

Two additional samples were incubated for a full day starting on June 11, one always exposed to full sunlight and the other exposed to a variable light regime on two occasions (incident irradiation alternated in 30 min intervals between $100 \% \mathrm{I}_{\circ}$ and $60 \% \mathrm{I}_{\circ}$ on June 11 and between $60 \% \mathrm{I}_{0}$ and $30 \% \mathrm{I}_{\circ}$ on July 16) and $30 \% I_{0}$ on the remaining dates. The last incubation of the day on September 29 was performed under full sunlight as well as at $60 \% \mathrm{I}_{\text {。 }}$.

Daily variations in solar irradiation (visible plus IR region) during the course of each study were measured at the study site with an International Light Radiometer (No. 700), whereas total daily irradiation (UV, visible, and IR) was recorded on an Eppley pyroheliometer located on the roof of the Clark Laboratory at WHOI, a short distance from where the experiments were performed.

We performed time-course measurements of ${ }^{14} \mathrm{C}$ uptake by introducing $\mathrm{H}^{14} \mathrm{CO}_{3}^{-}$at the start of an incubation to yield a specific activity of 80 to 100 $\mu \mathrm{Ci} \cdot$ mMole $\mathrm{DIC}^{-1}$, followed by subsampling $(10 \mathrm{ml})$ at about $15 \mathrm{~min}$ intervals for the first $30 \mathrm{~min}$, then at 90 min intervals, and finally at $60 \mathrm{~min}$ intervals for the balance of the incubation. The samples were processed by pipeting the $10 \mathrm{ml}$ into a scintillation vial containing enough $18 \mathrm{~N} \mathrm{H}_{2} \mathrm{SO}_{4}$ to lower the $\mathrm{pH}$ to 1.3. The vial contents were then sparged with pure nitrogen gas $\left(200 \mathrm{ml} \mathrm{min}{ }^{-1}\right)$ for $15 \mathrm{~min}$ to remove ${ }^{14} \mathrm{CO}_{2}$, and $5 \mathrm{ml}$ were added to another scintillation vial containing $9 \mathrm{ml}$ of Aquasol. Radioactivity was measured by liquid scintillation counting on a Beckman LS-100C instru-

Table 1. Summary of environmental conditions and rates of primary productivity in Vineyard Sound, Massachusetts, based on full-day single end-point measurements at $\mathrm{I}_{0}, 60 \% \mathrm{I}_{0}$, and $30 \% \mathrm{I}_{0}$ light levels

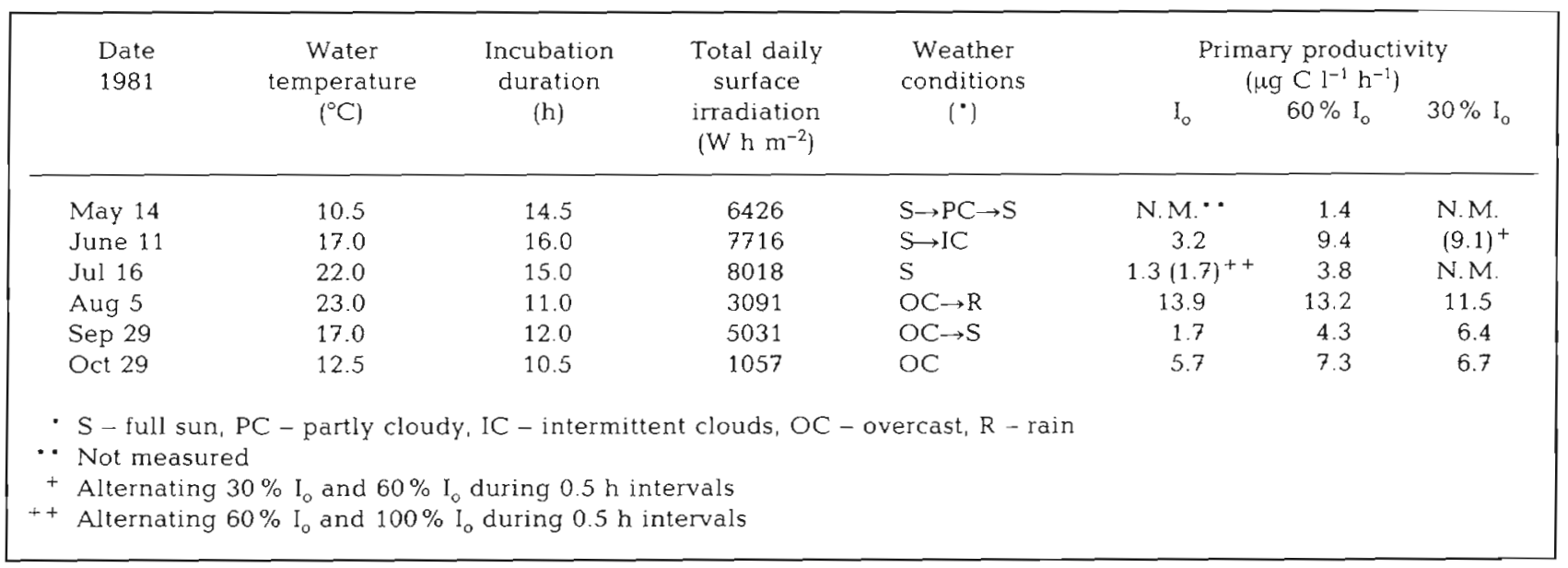


ment. The measured radioactivity represents the sum of labelled particulate and non-volatile dissolved organic carbon (Schindier and Holmgren, 1971).

On 3 occasions (June 11, August 5, September 29) additional filtered samples representing only labelled particulate carbon from the full day $\left(60 \% \mathrm{I}_{0}\right)$ incubations were processed for ${ }^{14} \mathrm{C}$ activity. $20 \mathrm{ml}$ subsamples, taken intermittently during the course of the incubations, were filtered immediately through Whatman GF/F glass-fiber filters. The filters first were rinsed with $50 \mathrm{ml}$ of filtered seawater and then placed in scintillation vials containing $10 \mathrm{ml}$ of Aquasol. Radioactivity was measured, as described above.

\section{Analytical methods}

Particulate carbon and particulate nitrogen were measured with a Perkin Elmer 240 elemental analyzer on samples retained on precombusted Whatman GF/F glass-fiber filters. Dissolved inorganic carbon (DIC) was measured on a Dohrmann PR-1 carbon analyzer (Goldman, 1979).

Portions of those samples collected before sunrise on each study day were filtered through $202 \mu \mathrm{m}$ Nitex mesh and preserved in Lugol's solution; phytoplankton cell counts and identifications were performed at a later date on $50 \mathrm{ml}$ subsamples according to the Utermöhl method (Lund et al., 1958).

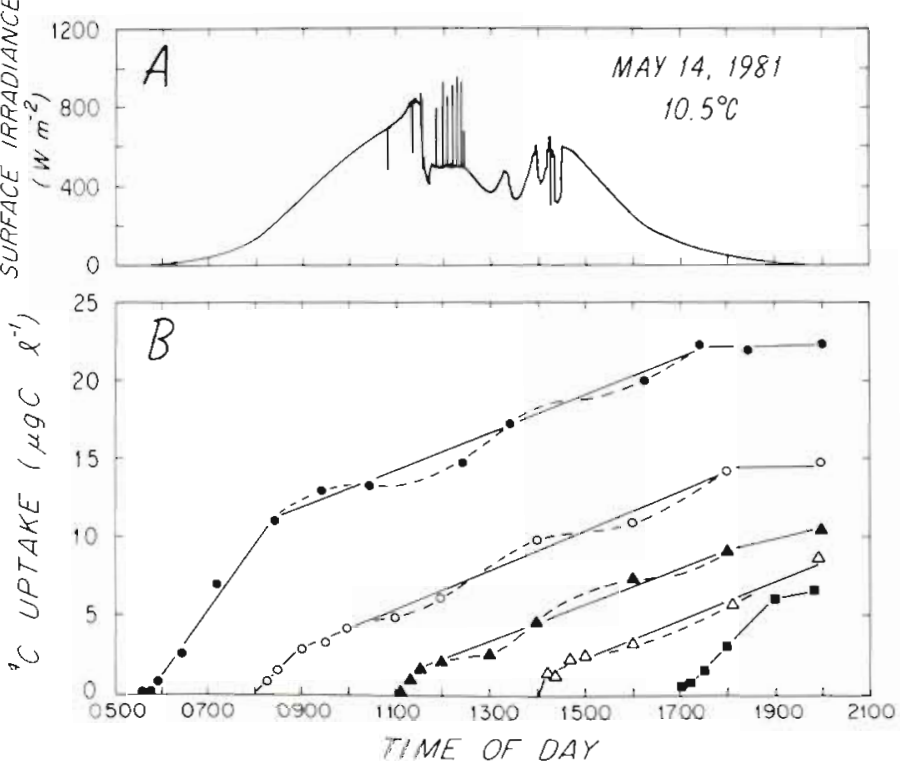

Fig. 1. Sequential incubations involving time-course measurements of ${ }^{14} \mathrm{CO}_{2}$ fixation by natural marine populations in Vineyard Sound, Massachusetts, May 14, 1981. (A) Solar irradiation. (B) ${ }^{14} \mathrm{CO}_{2}$ fixation of samples incubated at $60 \% \mathrm{I}_{0}$ : incubations started at $0530 \bullet, 08000,1100 \wedge, 1400 \triangle, 1700$. Curves in all figures were drawn by inspection. Solid lines: presumed linear uptake; dashed lines: possible rapid response to changing irradiation

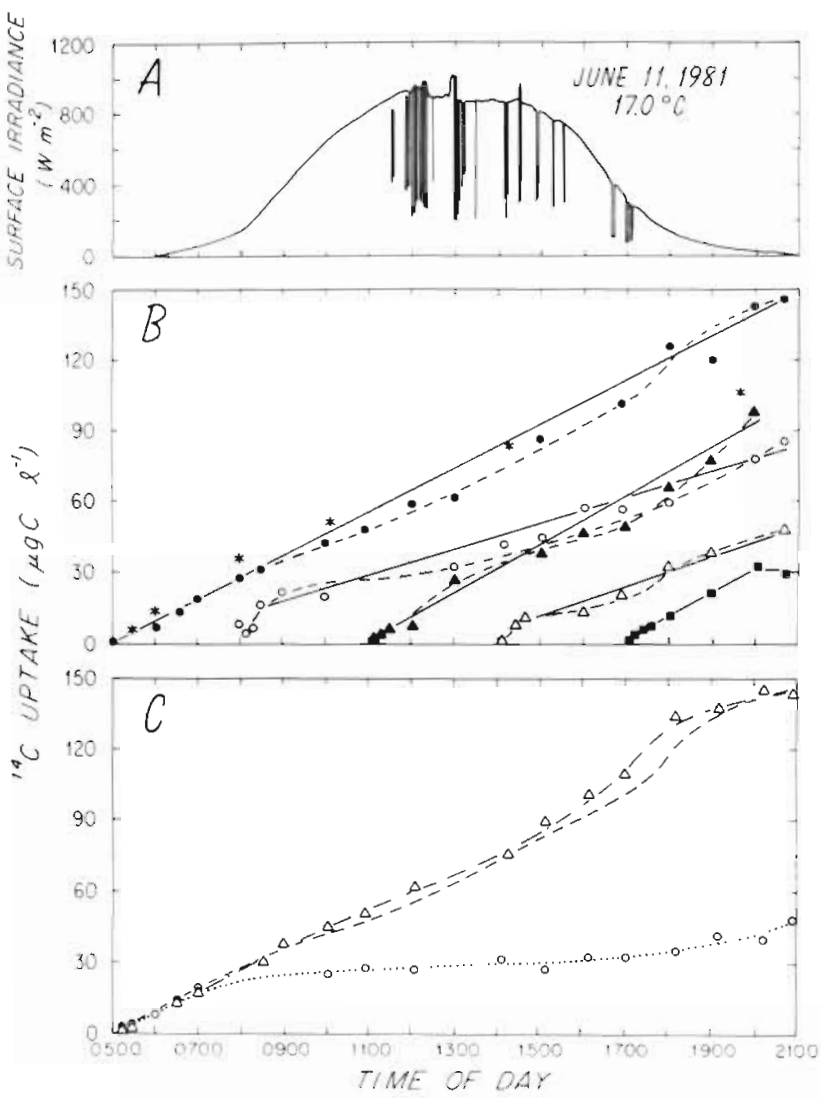

Fig. 2. Sequential incubations involving time-course measurements of ${ }^{14} \mathrm{CO}_{2}$ fixation by natural marine populations in Vineyard Sound, Massachusetts, June 11, 1981. (A) Solar irradiation. (B) ${ }^{14} \mathrm{CO}_{2}$ fixation of samples incubated at $60 \% \mathrm{I}_{\mathrm{o}}$ : incubations started at $0500 \bullet$; filtered samples $* 08000,1100$ $\Delta, 1400 \triangle, 1700$. (C) Full day incubations at $100 \% \mathrm{I}_{0}(\mathrm{O})$; alterating light between $30 \% \mathrm{I}_{\mathrm{o}}$ and $60 \% \mathrm{I}_{0}$ in $0.5 \mathrm{~h}$ intervals $\triangle$. Dashed line: full day incubation curve at $60 \% \mathrm{I}_{0}$ from Panel (B)

\section{RESULTS}

\section{Climatic conditions and water characteristics}

Climatic conditions varied tremendously between study days over the 6 mo period (Table 1). Only 1 of the $6 \mathrm{~d}$, July 11, was cloudless (Panel A in Fig. 1 to 6). On 2 occasions otherwise sunny days were interrupted by mid-day clouds: heavy overcast on May 14 (Fig. 1 A) and intermittent clouds on June 11 (Fig. 2 A). September 29, in contrast, was characterized by morning overcast, followed by mid-day clearing (Fig. 5 A). On 2 dates, August 5 and October 29, full day overcast prevailed (Fig. $4 \mathrm{~A}$ and $6 \mathrm{~A}$ ). The August 5 experiment, in fact, had to be terninated at $1600 \mathrm{~h}$ due to a thunderstorm. With the exception of the 2 overcast dates, total daily irradiation on the study days varied between about 5000 and $8000 \mathrm{~W} \mathrm{~h} \mathrm{~m}^{-2}$ (Table 1). Water temper- 
Table 2. Summary of particulate carbon and particulate nitrogen data of individual samples obtained from Vineyard Sound, Massachusetts during 6 mo study period

\begin{tabular}{|c|c|c|c|c|}
\hline $\begin{array}{l}\text { Date } \\
1981\end{array}$ & $\begin{array}{l}\text { Sampling } \\
\text { time }\end{array}$ & $\begin{array}{c}\text { Particulate } \\
\text { carbon } \\
\left(\mu \mathrm{g} \mathrm{C} \mathrm{l}^{-1}\right)\end{array}$ & $\begin{array}{c}\text { Particulate } \\
\text { nitrogen } \\
\left(\mu g \mathrm{~N}^{-1}\right)\end{array}$ & $\begin{array}{c}C: N \text { ratio } \\
(w t: w t)\end{array}$ \\
\hline \multirow[t]{5}{*}{ May 14} & 0530 & 264 & 31 & 8.5 \\
\hline & 0800 & 627 & 77 & 8.1 \\
\hline & 1100 & 457 & 59 & 7.7 \\
\hline & 1400 & 962 & 103 & 9.3 \\
\hline & 1700 & 847 & 99 & 8.6 \\
\hline \multirow[t]{5}{*}{ Jun 11} & 0500 & 750 & 80 & 9.4 \\
\hline & 0800 & 730 & 81 & 9.0 \\
\hline & 1100 & 685 & 74 & 9.3 \\
\hline & 1400 & 690 & 73 & 9.5 \\
\hline & 1700 & 985 & 79 & 12.5 \\
\hline \multirow[t]{5}{*}{ JuI 16} & 0500 & 748 & 89 & 8.4 \\
\hline & 0800 & 454 & 66 & 6.9 \\
\hline & 1100 & 632 & 79 & 8.0 \\
\hline & 1400 & 691 & 69 & 10.0 \\
\hline & 1700 & 633 & 70 & 9.0 \\
\hline \multirow[t]{4}{*}{ Aug 5} & 0500 & 623 & 86 & 7.2 \\
\hline & 0800 & 573 & 78 & 7.3 \\
\hline & 1100 & 1110 & 136 & 8.2 \\
\hline & 1400 & 670 & 85 & 7.9 \\
\hline \multirow[t]{4}{*}{ Sep 29} & 0615 & 637 & 77 & 8.3 \\
\hline & 0915 & 740 & 92 & 8.0 \\
\hline & 1215 & 718 & 91 & 7.9 \\
\hline & 1515 & 1083 & 134 & 8.1 \\
\hline \multirow[t]{4}{*}{ Oct 29} & 0600 & 340 & 41 & 8.3 \\
\hline & 0900 & 261 & 33 & 7.9 \\
\hline & 1200 & 190 & 24 & 7.9 \\
\hline & 1430 & 152 & 20 & 7.6 \\
\hline
\end{tabular}

atures varied in a more predictable fashion, increasing from $10.5^{\circ} \mathrm{C}$ on May 14 to a maximum of $23^{\circ} \mathrm{C}$ on August 5 , followed by a decrease to $12.5^{\circ} \mathrm{C}$ on October 29 (Table 1).

We could not find any evidence of diel or seasonal changes in the concentrations of particulate carbon and particulate nitrogen during the first five study days (Table 2). For the most part, the particulate carbon and particulate nitrogen concentrations varied irregularly between about $600-750 \mu \mathrm{g} \mathrm{l}^{-1}$ and $60-90 \mu \mathrm{g} 1^{-1}$, respectively, over the course of each study day, although higher and lower concentrations of both constituents were measured from time to time. Concentrations of both particular constituents, not only were minimal on October 29, but decreased over the course of the day. The particulate $\mathrm{C}: \mathrm{N}$ ratio was reasonably constant at about 8 (wt: wt) during most of the study period, although on June 11 it was $>9$.

Assorted diatoms and cryptomonads were the most abundant phytoplankton species during the six month period (Table 3). The cryptomonads Chroomonas amphioxeia and C. minuta comprised between 64 and $85 \%$ of the total number of phytoplankton cells between May 14 and July 16. Assorted diatoms made up the balance of the cell population during this period. The diatom fraction (dominated by Leptocylindrus danicus on August 5, and Rhizosolenia stolterfothii on September 29) increased from late summer through early fall, reaching $92 \%$ of the total cell population by September 29; the cryptomonad contribution, in contrast, decreased dramatically to only $7 \%$ of the total population during this same period. By October 29 when biomass concentrations were lowest (Table 2) there was an even balance between diatoms and cryptomonads ( $43 \%$ each), with an unidentified dinoflagellate comprising the remainder of the population.

\section{Time course of primary production}

The 2 patterns of ${ }^{14} \mathrm{C}$ uptake we observed seemed to be correlated with season. On the first 2 study dates in May and June (Fig. 1 B and 2 B) and again in September (Fig. 5 B) rapid initial uptake, which occurred during all but the last daily back to back incubation of each day, was followed by reduced uptake over the balance of the incubation period and, in some cases, cessation of uptake late in the day. The duration over which the initial rapid phase was sustained seemed to decrease with increasing time of day. This type of response was most apparent on May 14 (Fig. 1 B) and on September 29 (Fig. 5 B). In fact, total ${ }^{14} \mathrm{C}$ uptake over the first $3 \mathrm{~h}$ of the day on these 2 dates accounted for $51 \%$ and $53 \%$, respectively, of the full day production (Table 4). In contrast, uptake during the last incubation of each day, not only was linear, but was about as rapid as during the first several hours of the first daily incubation.

Although we drew straight (solid) lines through the data to indicate the trends of uptake in Fig. 1 B, 2 B, and $5 \mathrm{~B}$, it appeared, particularly during the May 14 and September 29 experiments, that mid-day suppression of ${ }^{14} \mathrm{C}$ uptake occurred when there were no or intermittent clouds. This suppression seemed to be alleviated either when heavy clouds passed over, as on May 14, or during the latter part of the afternoon on all 3 dates when sunlight intensity decreased significantly. This trend, as shown by the dashed lines in Fig. $1 \mathrm{~B}, 2 \mathrm{~B}$, and $5 \mathrm{~B}$, was apparent in all but the last incubation of each day. It was impossible to assign error bars to the individual datum points in each experiment because we only sampled once at each time interval and the incubations were not replicated. Thus there is some uncertainty as to whether the apparent rapid responses to changing sunlight were real. The consistency of the trends from one incubation to 
Table 3. Summary of major phytoplankton species present in Vineyard Sound, Massachusetts at time of pre-dawn sampling during 6 mo study period between May 14, 1981 and October 29, 1981

\begin{tabular}{|c|c|c|c|c|c|c|}
\hline \multirow[t]{2}{*}{ Species } & \multicolumn{6}{|c|}{ Cell Count (cells $\mathrm{ml}^{-1}$ ) } \\
\hline & May 14 & Jun 11 & Jul 16 & Aug 5 & Sep 29 & Oct 29 \\
\hline \multicolumn{7}{|l|}{ Diatoms } \\
\hline Navicula sp. & & & & & 13 & \\
\hline Cylindrotheca closterium & 3 & 42 & 4 & & & 11 \\
\hline Leptocylindrus danicus & 82 & & & 106 & 26 & 33 \\
\hline $\begin{array}{l}\text { Rhizosolenia imbricata var. } \\
\text { schrubsolei }\end{array}$ & & & 4 & 40 & & 4 \\
\hline Rhizosolenia delicatula & & & 12 & 24 & & 5 \\
\hline Rhizosolenia calcar-avis & & & & 13 & & \\
\hline Rhizosolenia setigera & & 11 & & & & \\
\hline Rhizosolenia stolterfothii & 13 & & & & 314 & 23 \\
\hline Skeletonema costatum & & 21 & & & & \\
\hline Skeletonema menzilii & & 37 & & & & \\
\hline Thalassiosira pseudonana & & & 14 & & & \\
\hline Assorted other diatoms & 18 & & 9 & 24 & 8 & 16 \\
\hline \multicolumn{7}{|l|}{ Dinoflagellates } \\
\hline $20 \mu \mathrm{m}$ unident. naked dinoflag. & & & & & & 28 \\
\hline Assorted other dinoflagellates & & 5 & 11 & 3 & 5 & \\
\hline \multicolumn{7}{|l|}{ Cryptomonads } \\
\hline Pyramimonas sp. & 8 & 26 & 11 & & 3 & \\
\hline Chroomonas amphioxeia & 145 & 16 & & & & 9 \\
\hline Chroomonas minuta & 26 & 227 & 275 & 153 & 21 & 48 \\
\hline Unknown sp. & 21 & 137 & 21 & & & 21 \\
\hline Assorted other cryptomonads & 8 & & 1 & & 3 & 14 \\
\hline \multicolumn{7}{|l|}{ Others } \\
\hline Unidentified $3 \mu \mathrm{m}$ sp. & & 42 & & 79 & & \\
\hline Dunaliella sp. & & & & 5 & & \\
\hline \multicolumn{7}{|l|}{ Total (Percentage) } \\
\hline Diatoms & 36 & 20 & 12 & 47 & 92 & 43 \\
\hline Dinoflagellates & 0 & $<1$ & 3 & $<1$ & 1 & 14 \\
\hline Cryptomonads & 64 & 73 & 85 & 34 & 7 & 43 \\
\hline Other and Unidentified & 0 & 7 & 0 & 19 & 0 & 0 \\
\hline
\end{tabular}

Table 4. Summary of total and incremental daily primary production estimates at $60 \% \mathrm{I}_{0}$ determined by full day, single end-point measurements (TP), by summed back to back $3 \mathrm{~h}$ rates $(\Sigma \mathrm{P})$, and by first $\mathrm{h}$ rate from each back to back incubation extrapolated to $3 \mathrm{~h}$ and summed over full day $\left(\Sigma \mathrm{P}^{\prime}\right)$

\begin{tabular}{|c|c|c|c|c|c|c|c|c|c|c|}
\hline \multirow[t]{2}{*}{$\begin{array}{l}\text { Date } \\
1981\end{array}$} & \multicolumn{3}{|c|}{$\begin{array}{l}\text { Total daily production } \\
\qquad\left(\mu \mathrm{g} \mathrm{C}^{-1}\right)\end{array}$} & \multicolumn{5}{|c|}{$\begin{array}{c}\text { Incremental daily production } \\
\% \Sigma \mathrm{P}(\% \mathrm{TP})\end{array}$} & \multirow[t]{2}{*}{$\begin{array}{l}\Sigma P: T P \\
\text { ratio }\end{array}$} & \multirow[t]{2}{*}{$\begin{array}{l}\Sigma \mathrm{P}^{\prime}: \mathrm{TP} \\
\text { ratio }\end{array}$} \\
\hline & $\mathrm{TP}$ & $\Sigma P$ & $\Sigma \mathrm{P}^{\prime}$ & $0-3 \mathrm{~h}$ & $3-6 \mathrm{~h}$ & $6-9 \mathrm{~h}$ & $9-12$ h & $12-15 \mathrm{~h}$ & & \\
\hline May 14 & 22.2 & 33.6 & 39.4 & $33(51)$ & 18 & 14 & 15 & 20 & 1.5 & 1.8 \\
\hline Jun 11 & 148.2 & 141.5 & 169.8 & $29(19)$ & 17 & 25 & 15 & 23 & 0.9 & 1.2 \\
\hline Jul 16 & 55.8 & 47.9 & 82.1 & $23(20)$ & 14 & 14 & 18 & 31 & 0.9 & 1.5 \\
\hline Aug 5 & 139.0 & 136.2 & 128.4 & $19(19)$ & 27 & 22 & $32^{\circ}$ & & 1.0 & 0.9 \\
\hline Sep 29 & 51.4 & 117.2 & 145.5 & 35 (53) & 22 & 10 & 33 & & 2.0 & 2.8 \\
\hline Oct 29 & 75.0 & 113.8 & 127.1 & 22 (33) & 32 & 32 & $14^{\circ}$ & & 1.5 & 1.7 \\
\hline
\end{tabular}

another and the similarity in the results between the May and September studies, however, appears to be more than coincidental, thereby providing us with some assurance that the rapid changes in ${ }^{14} \mathrm{C}$ uptake were real.
The second uptake pattern was one in which linear uptake was more persistent during each incubation. This response was observed on July 16 (Fig. 3 B) when there were virtually no clouds and high total iradiation (8018 $\mathrm{W} \mathrm{h} \mathrm{m}^{-2}$ ) and on both August 5 (Fig. $4 \mathrm{~B}$ ) and 
October 29 (Fig. 6 B), days marked by heavy overcast and very low total irradiation (3091 and $1057 \mathrm{~W} \mathrm{~h} \mathrm{~m}^{-2}$, respectively).

\section{Response to different light regimes}

A common feature of each experiment was that regardless of weather conditions, uptake of ${ }^{14} \mathrm{C}$ over the first few hours of the full day incubations was maximal and unaffected by variations in the imposed light regime (Fig. $2 \mathrm{C}-6 \mathrm{C}$ ). On sunny days, however, we found that ${ }^{14} \mathrm{C}$ uptake quickly ceased after a few hours in those incubation vessels exposed to full sunlight for the entire day (Fig. $2 \mathrm{C}, 3 \mathrm{C}$ and $5 \mathrm{C}$ ) and that the mid-day suppression in productivity (which was common to the incubations at $60 \% I_{0}$ ) was less pronounced when the light was reduced to $30 \% \mathrm{I}_{0}$ (Fig. 5 C). Rapid suppression of ${ }^{14} \mathrm{C}$ uptake likewise occurred on a sunny day when the last incubation of the day was performed without screening, although recovery in uptake under these conditions seemed to occur just before sunset (Fig. 5 C). On cloudy days there was virtually no impact of light attenuation (down to $30 \%$ $\mathrm{I}_{0}$ ) on the time course of ${ }^{14} \mathrm{C}$ uptake over the entire day (Fig. $4 \mathrm{C}$ and $6 \mathrm{C}$ ).

Alternating the light between $30 \% \mathrm{I}_{0}$ and $60 \% \mathrm{I}_{0}$ had about the same effect on ${ }^{14} \mathrm{C}$ uptake as did con-

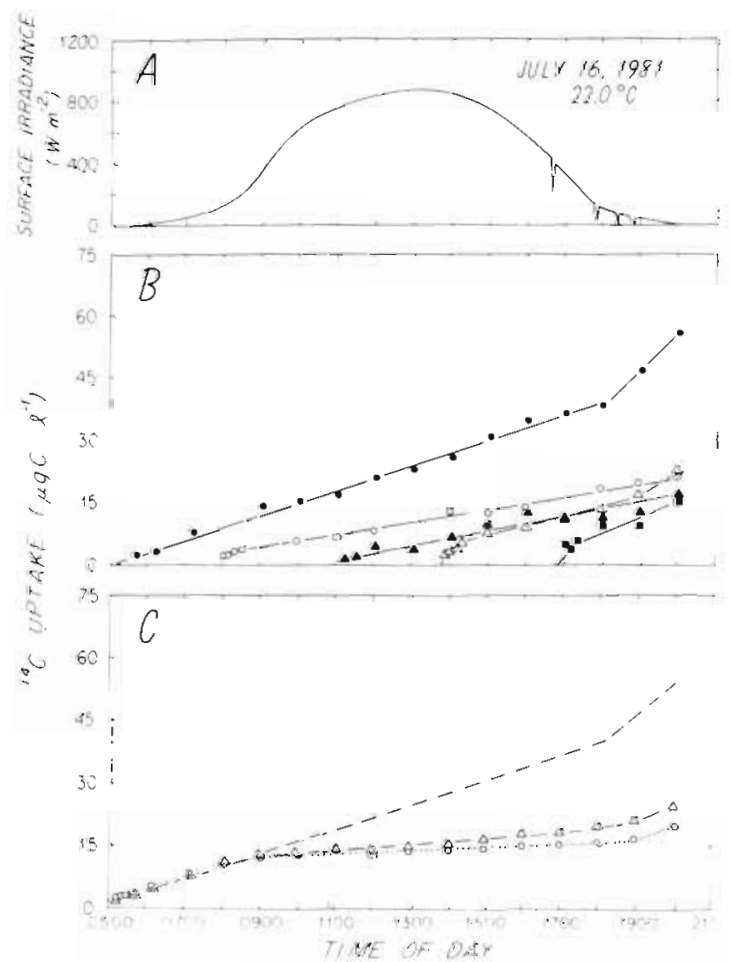

Fig. 3. Same as Fig. 2, except performed on July 16, 1981 and $\Delta$ in Panel (C) represents alternating light between $60 \% \mathrm{I}$ and $100 \% \mathrm{I}_{0}$ in $0.5 \mathrm{~h}$ intervals

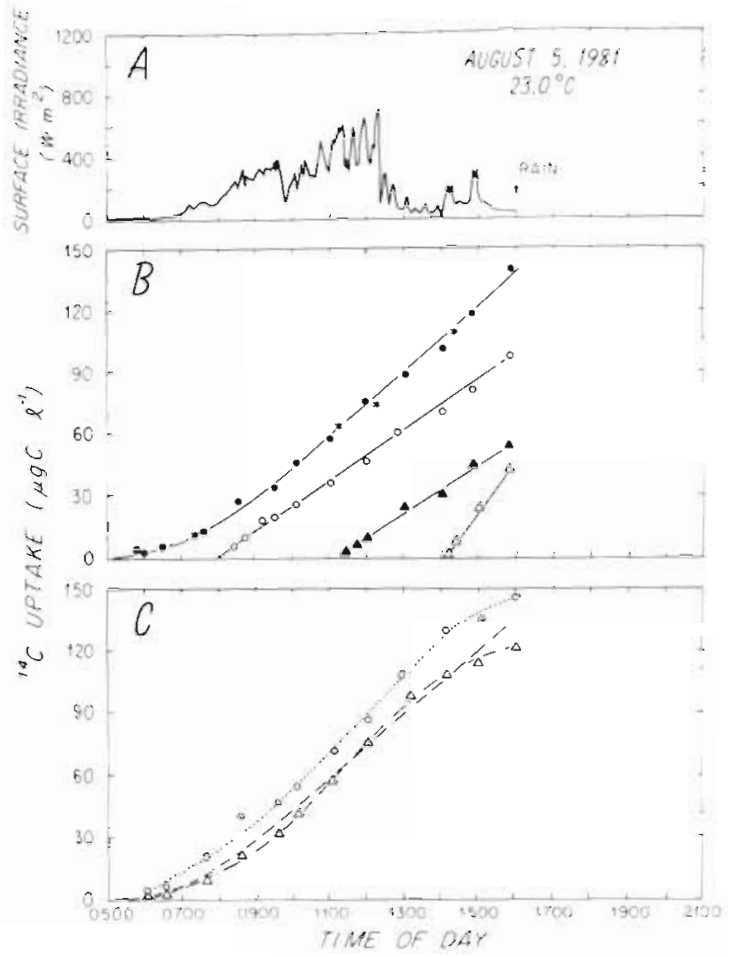

Fig. 4. Same as Fig. 2, except performed on August 5, 1981 and $\triangle$ in Panel (C) represents incubation under $30 \% \mathrm{I}$ 。

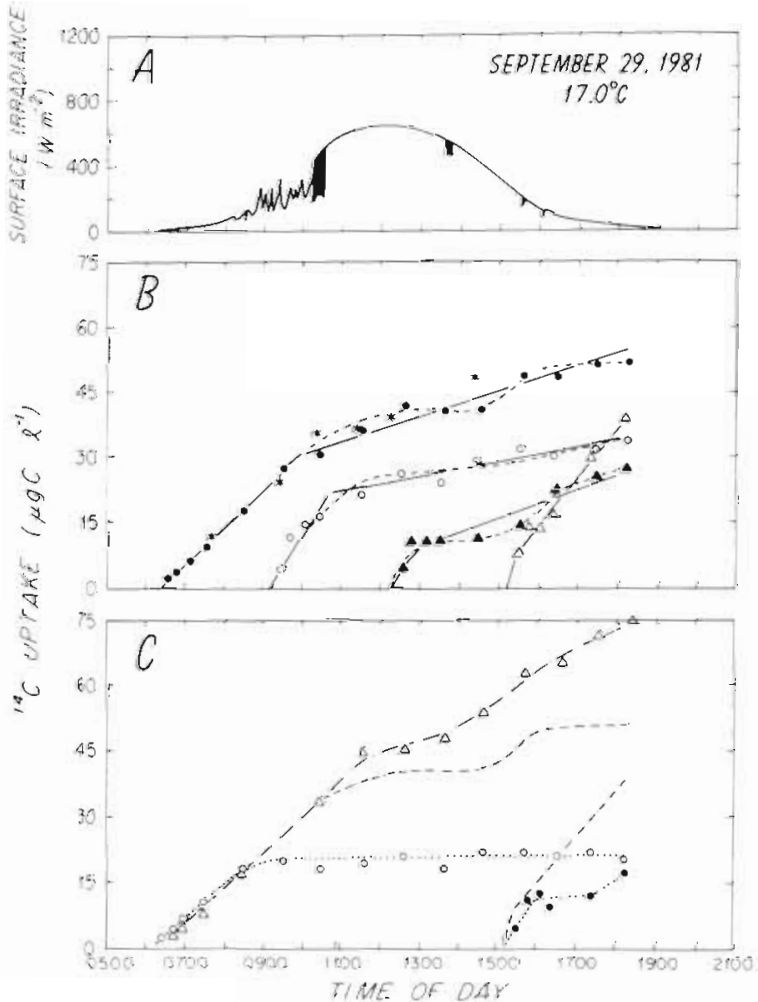

Fig. 5. Same as Fig. 4, except performed on September 29. 1981 and - in Panel (C) represents incubation starting at 1500 under $100 \% \mathrm{I}_{0}$. Dashed line: 1500 incubation curve at $60 \% \mathrm{I}_{0}$ from Panel (B) 


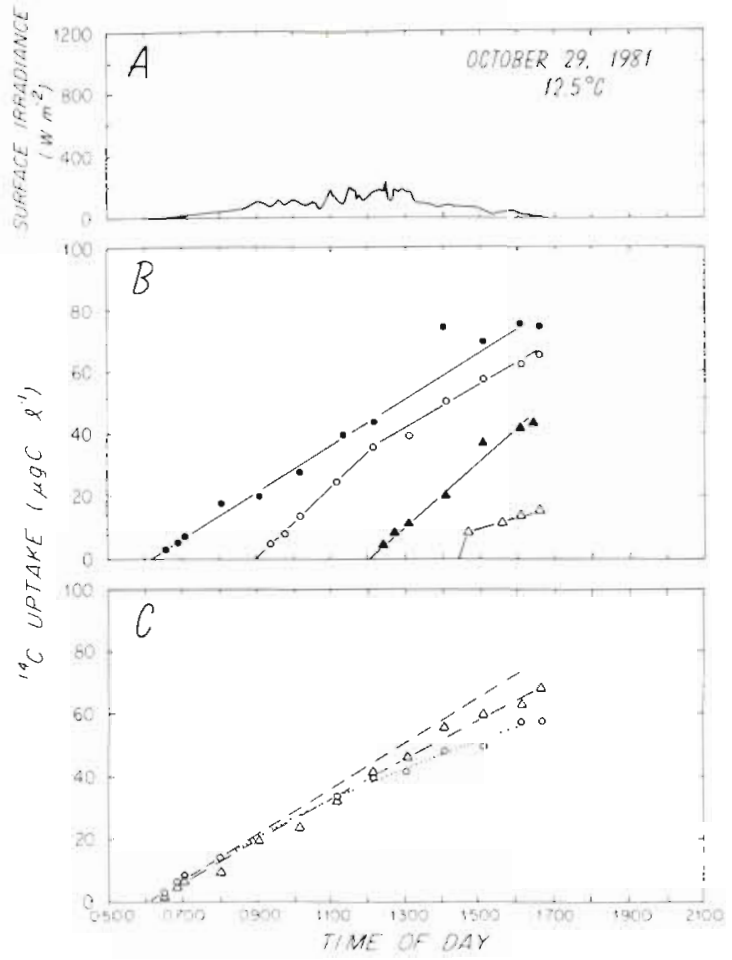

Fig. 6. Same as Fig. 4, except performed on October 29, 1981

stant light reduced to $60 \% \mathrm{I}_{0}$ (Fig. 2 C). Similarly, there was no appreciable improvement in ${ }^{14} \mathrm{C}$ uptake in the vessel exposed to alternating light between $60 \% \mathrm{I}_{0}$ and $100 \% \mathrm{I}_{0}$ compared to the one maintained constantly at full sunlight (Fig. $3 \mathrm{C}$ ).

\section{Primary productivity estimates}

We estimated primary productivity in 3 different ways. First, total daily production based on single endpoint measurements from the full day incubations was normalized to an hourly rate (TP). By this technique we observed that rates of productivity on a given day generally were saturated by at least $30 \% \mathrm{I}_{0}$. These rates were sustained or only slightly altered at $60 \% \mathrm{I}_{0}$, but did decrease significantly under full sunlight on June 11, July 16 and September 29 when total irradiation exceeded $5000 \mathrm{~W} \mathrm{~h} \mathrm{~m}^{-2}$ (Table 1). On the 2 overcast days, August 5 and October 29, exposure to full sunlight had little adverse effect on productivity.

There was no discernable seasonal trend in productivity rates (Table 1 ). Maximum rates of $\sim 13 \mu \mathrm{gC} \mathrm{I}^{-1}$ $\mathrm{h}^{-1}$ occurred on August 5 when water temperature was $23^{\circ} \mathrm{C}$ and total irradiation was $3091 \mathrm{~W} \mathrm{~h} \mathrm{~m}^{-2}$, whereas lowest rates of $1.4 \mu \mathrm{gC}^{-1} \mathrm{~h}^{-1}$ were found on May 14 when water temperatures were $10.5^{\circ} \mathrm{C}$ and total irradiation was $6426 \mathrm{~W} \mathrm{~h} \mathrm{~m}^{-2}$. The general trend was for productivity to be highest when days were overcast and lowest when sunny weather prevailed.

The other estimates of productivity were based on summing total production at $60 \% \mathrm{I}_{\circ}$ over the first $3 \mathrm{~h}$ of each back to back incubation during the course of a day $(\Sigma P)$ and extrapolating the first hour rate from each back to back incubation to $3 \mathrm{~h}$ total production values and then summing these values as in the previous method ( $\left.\Sigma \mathrm{P}^{\prime}\right)$. These estimates of total daily production were then compared with estimates based on single-end-point measurements from the full day incubations at $60 \% \mathrm{I}_{\circ}$ (TP). Accordingly, we found the ratio $\Sigma$ P:TP to be $>1$ in the spring and fall, ranging between 1.5 on May 14 and October 29 to 2.0 on September 29. During the summer period $\Sigma \mathrm{P}: \mathrm{TP}$ was between 0.9 and 1.0 (Table 4). With the exception of the August 5 experiment, the ratio $\Sigma P^{\prime}$ : TP was greater than $\Sigma$ P: TP on each study date (Table 4).

On the 3 occasions when we compared the time course of total ${ }^{14} \mathrm{C}$ uptake (particulates plus excretion products) with uptake into the particulate fraction only (Fig. 2 B, 4 B, and 5 B), we found no difference between the 2 methods, indicating that there was little, if any, excretion of dissolved organics.

\section{Mixing in Vineyard Sound}

Our sampling station in Vineyard Sound was located in a shallow region ( $\sim 10 \mathrm{~m}$ depth) where tidal flushing is strong and vertical mixing is virtually complete throughout the year, as judged from numerous bathythermograms compiled at WHOI (Bumpus et al., 1971). Our inability to observe thermal stratification at this location over a 15 mo period in 1979-1980 (unpubl.) in conjunction with another study (Glibert et al., 1982) confirms this conclusion. In addition, $>97 \%$ of incident irradiation always was attenuated at $10 \mathrm{~m}$ depth (unpubl.). Thus, although we have no information on vertical mixing velocities, it appears reasonable to assume that the resident phytoplankton populations that we collected were never photoadapted to any particular light level.

\section{DISCUSSION}

\section{Time course of photoinhibition}

As summarized in Harris (1978, 1980), photoinhibition is a well-established, if poorly understood phenomenon. Often little or no distinction is made between the various processes that can cause a decrease in photosynthesis at supersaturating light intensity (e.g. UV and visible photochemical decay, photorespiration, photooxidation); thus in most 
studies, including this one, the term 'photoinhibition' is used to lump together all processes leading to a decrease in the rate of $\mathrm{CO}_{2}$ fixation at high irradiation.

The manifestation of photoinhibition during bottle incubations of natural water samples depends on at least 3 key factors: (1) light history of the confined population (stratified versus well-mixed phytoplankton), (2) incubation irradiation, and (3) duration of exposure to greater than saturating irradiation. The last factor, although recognized as being of crucial importance in the interpretation of bottle productivity measurements (Harris, 1978, 1980) and in the modelling of P versus I relationships (Platt et al., 1980), is poorly characterized.

From the earlier time-course studies of Myers and Burr (1940) and Kok (1956), it was evident that algae, when exposed to light intensities far greater than saturating, were capable of sustaining maximum photosynthetic rates for short (minutes) duration before a progressive decay in photosynthesis occurred. Others have observed this phenomenon in studies on cultured and natural populations of phytoplankton (Takahashi et al., 1971; Harris and Piccinin, 1977; Belay, 1981). Harris (1980) suggested that photoinhibitory effects not only would become progressively manifested at light intensities $>200 \mu \mathrm{E} \mathrm{m} \mathrm{ml}^{-2} \mathrm{~s}^{-1}\left(-50 \mathrm{~W} \mathrm{~m}^{-2}\right)$, but that of Harris (1980). In fact, on close scrutiny of the May 14 and September 29 results when photoinhibition was most apparent, it appeared that, even though the light level leading to photoinhibition was ca. $130 \mathrm{~W} \mathrm{~m}^{-2}$ (as judged by the light level corresponding to the point of departure from initially rapid $\mathrm{CO}_{2}$ fixation during the first incubation of the day [Fig. $1 \mathrm{~B}$ and $5 \mathrm{~B}$ ]), it was possible for initially rapid photosynthetic rates to be sustained for 15 to $30 \mathrm{~min}$ periods during mid-day incubations when light levels had exceeded 300 $\mathrm{W} \mathrm{m}^{-2}$ (Table 5).

However, during summer (June-August), not only was photoinhibition hardly evident during the $60 \% \mathrm{I}_{0}$ incubation experiments, but in the unscreened experiments it seemed to occur at increasingly higher sunlight intensities as the summer progressed. For example, on July 16 (a cloudless day) photoinhibition developed only when irradiation reached $400 \mathrm{~W} \mathrm{~m}^{-2}$ (Fig. $3 \mathrm{C}$ ); and on August 5 (a variably cloudy day) photoinhibition never was experienced even though sunlight intensities reached $600 \mathrm{~W} \mathrm{~m}^{-2}$ at times (Fig. 4 C). The reasons for this seasonal change in the patterns of photoinhibition are unclear, but the results are strikingly similar to those of Marra (1978b) and Hobson and Hartley (1983), both of whom found no evidence for suppression in surface productivity of coastal waters

Table 5. Effect of time of day when incubation was initiated on durations of exposure and the irradiation leading to strong photoinhibition on May 14, 1981 and on September 29, 1981

\begin{tabular}{|c|c|c|c|c|}
\hline $\begin{array}{l}\text { Date } \\
1981\end{array}$ & $\begin{array}{l}\text { Time of day } \\
\text { incubation } \\
\text { initiated }\end{array}$ & $\begin{array}{l}\text { Starting } \\
\text { irradiation } \\
\left(\mathrm{W} \mathrm{m} \mathrm{m}^{-2}\right)\end{array}$ & 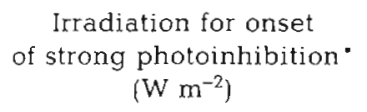 & $\begin{array}{l}\text { Duration of exposure } \\
\text { before onset of strong } \\
\text { photoinhibition (min) }\end{array}$ \\
\hline May 14 & $\begin{array}{l}0530 \\
0800 \\
1100 \\
1400\end{array}$ & $\begin{array}{r}0 \\
85 \\
430 \\
360\end{array}$ & $\begin{array}{l}130 \\
200 \\
540 \\
360\end{array}$ & $\begin{array}{r}180 \\
60 \\
30 \\
15\end{array}$ \\
\hline Sep 29 & $\begin{array}{l}0630 \\
0915 \\
1215\end{array}$ & $\begin{array}{r}0 \\
150 \\
330\end{array}$ & $\begin{array}{c}130-260(130)^{\cdots} \\
320 \\
325\end{array}$ & $\begin{array}{r}240(135) \cdots \\
75 \\
15\end{array}$ \\
\hline $\begin{array}{r}\text { - Irradia } \\
\text { and } 5 \mathrm{E} \\
\cdots \text { Irradia } \\
\cdots \text { Time } \mathrm{f}\end{array}$ & $\begin{array}{l}\text { ich major red } \\
\text { ig to comple } \\
\text { e inhibition }\end{array}$ & $\begin{array}{l}{ }^{14} \mathrm{C} \text { uptak } \\
\text { ncubation ve }\end{array}$ & $\begin{array}{l}\text { occurred (incubation vessels } \\
\text { posed to } 100 \% I_{o^{\prime}} \text { Fig. } 5 \mathrm{C} \text { ) }\end{array}$ & posed to $60 \% I_{0}$, Fig. $1 \mathrm{~B}$ \\
\hline
\end{tabular}

exposure to sunlight irradiation $>800-1000 \mu \mathrm{E} \mathrm{m}^{-2} \mathrm{~s}^{-1}$ $\left(\sim 200-250 \mathrm{~W} \mathrm{~m}^{-2}\right)$ for periods exceeding $30 \mathrm{~min}$ would lead to severe photoinhibition and that maximum photosynthesis under such conditions was possible for only 10 to $20 \mathrm{~min}$.

Our observation that the onset of photoinhibition generally was preceded by a period of rapid initial $\mathrm{CO}_{2}$ fixation, and that the duration of this period was inversely related to the light level at the start of an incubation (Table 5), is in accord with the conclusions during late spring-early summer when surface irradiation was maximal, but pronounced surface suppression before or after this period. Hobson and Hartley (1983) attributed this seasonal suppression of photosynthesis to a greater susceptibility to UV-inhibition by diatoms, species which were dominant during the period of surface suppression. We cannot rule out this possibility in our experiments, but we suspect that little, if any, UV light passed the double glass walls and layer of cooling water of our incubation vessels. 
Considering the intense mixing of Vineyard Sound throughout the year, it is also difficult to invoke a photoadaptive mechanism for the summer resistance to photoinhibition we observed. Major changes in water temperature $\left(10.5^{\circ} \mathrm{C}\right.$ on May 14 to $23.0^{\circ} \mathrm{C}$ on August 5) and phytoplankton species (Table 3 ) did occur during this period and one or both of these variables may be correlated with the seasonal change we saw in photoinhibition light intensities.

A strong interrelationship exists between temperature and light in regulating photosynthesis in phytoplankton (Cloern, 1977; Yoder, 1979). Yet, little is known of any possible relationship between temperature and the time-course of photoinhibition, although, as summarized by Harris (1980), recovery from photoinhibition appears to be temperature-dependent. In an earlier study (Goldman et al., 1981) we found that under constant light intensity the incubation period for which linear $\mathrm{CO}_{2}$ fixation was maintained by the marine diatom Thalassiosira weissflogii decreased systematically with decreasing temperature. Whether this temperature-dependent reduction in photosynthetic capacity over time was a true photoinhibitory response is not known, but the results are suggestive of a role for temperature in regulating the exposure period over which a particular P vs I relationship holds.

Concomitant with the increased resistance to photoinhibition between May 14 and July 16 that occurred in the incubated samples there was a decrease in the diatom fraction and an increase in the cryptomonads (Table 3). Cryptomonads, because of their small size relative to the diatoms, probably contributed considerably less to total primary production than their numbers would indicate.

Comparisons of the photosynthetic characteristics of laboratory-grown cryptomonads and diatoms provide no real clue as to why the Vineyard Sound summer phytoplankton were uniquely resistant to photoinhibition. Light saturation in many diatoms (Richardson et al., 1983) and in the few studied cryptomonads (Faust and Gantt, 1973; Cloern, 1977; Morgan and Kalff, 1979) seems to occur at intensities in the range 75 to $150 \mu \mathrm{E} \mathrm{m}^{-2} \mathrm{~s}^{-1}\left(\sim 40\right.$ to $\left.80 \mathrm{~W} \mathrm{~m}^{-2}\right)$. Similarly, photoinhibitory light intensities in many diatoms and in one freshwater cryptomonad (Morgan and Kalff, 1979) have been reported to be typically in the range of 150 to $>330 \mu \mathrm{E} \mathrm{m}^{-2} \mathrm{~s}^{-1}\left(-20\right.$ to $\left.40 \mathrm{~W} \mathrm{~m}^{-2}\right)$, although the higher values are from one study in which meticulous care was taken to insure long-term adaptation to the imposed light intensities (Brand and Guillard, 1981). Yet, we never observed photoinhibition at any time during the 6 mo study until light intensities $>130 \mathrm{~W}$ $\mathrm{m}^{-2}$ were reached. Moreover, because the maximum slopes of the times-course curves generally were attained at the onset of the first morning incubations, sometimes in vessels attenuated to $30 \% \mathrm{I}_{0}$ (Fig. $3 \mathrm{C}$ to $6 \mathrm{C})$, and again during the last incubations of the day at $60 \% \mathrm{I}_{0}$, light saturation levels always appeared to be very low.

Although little is known of the light response characteristics of natural cryptomonad populations, there is some convincing evidence that natural diatom populations become photoinhibited at much lower sunlight levels during bottle incubations than do a variety of other classes of phytoplankton (Harris and Piccinin, 1977; Platt et al., 1980). Platt et al., for example, found that even though natural populations of marine diatoms from well-mixed waters photoinhibited at light levels far above the expected values $\left(\sim 140 \mathrm{~W} \mathrm{~m}^{-2}\right)$, other classes of species, including flagellates from the same waters consistently did not display photoinhibition at sunlight intensities $>600$ $\mathrm{W} \mathrm{m}^{-2}$. These results are in accord with our findings and lead us to believe that the mechanisms controlling photoinhibition in natural populations are far different than what might be ascertained from a laboratory P vs I experiment. The notion that cryptomonads may, as a rule, be more resistant to photoinhibition than diatoms does not explain the August 5 results when the diatom fraction had risen back to $47 \%$ of the total cell population and still there was no evidence of photoinhibition.

It is difficult to speculate further on the causes of the seasonal variations in photoinhibition we observed. Our results point toward rather complicated interactions between light, temperature, species, and exposure period controlling observed photoinhibition. Light intensity alone probably was not the main contributing factor in our experiments because total daily irradiation during May was comparable to mid-summer intensities (Table 1).

The link we observed between apparent recovery from photoinhibition and the combination of exposure duration and photoinhibiting light intensity (Fig. $5 \mathrm{C}$ ) is consistent with the early findings of Myers and Burr (1940). They showed that: (1) the greater the photoinhibiting light intensity and duration of exposure, the longer the period required before cultures of microalgae were able to recover from photoinhibition when placed under subsaturating light, and (2) photoinhibition was permanent above critical light levels and exposure periods. The differences between the rapid recovery from photoinhibition we saw on both May 14 when a cloud bank rapidly passed over at mid-day (Fig. 1 B) and September 29 when surface irradiation decreased late in the day (Fig. $5 \mathrm{C}$ ) and the permanent photoinhibition that occurred on July 16 under an alternating light regime (Fig. $3 \mathrm{C}$ ) may also have been species-related. Cryptomonads, although possibly able to withstand high supersaturating light intensities for short periods, may become permanently damaged 
when photoinhibition finally is manifested. Initial photoinhibition could be the result of photochemical decay, which is repairable (Sorokin, 1960), followed by photooxidative processes leading to complete chlorophyll degradation (Myers and Burr, 1940). Diatoms, in contrast, may exhibit photochemical decay at relatively lower light levels, perhaps as a protective strategy against photooxidation so that rapid recovery is possible once the light level is reduced late in the afternoon or at other times either through downward transport of cells in the water column or by cloud cover. Differences in the accessory pigment structure between diatoms and cryptomonads (Goodwin, 1974) may have something to do with these different patterns of photoinhibition.

\section{Bottle photoinhibition and primary production estimates}

The extent to which water-column productivity in a shallow environment such as Vineyard Sound may be underestimated by use of bottle incubations is not easily predictable. The unexpected nature of the seasonal response of natural populations to full sunlight in our study and in those of Marra (1978b) and Hobson and Hartley (1983) raises perplexing questions about the very nature of photoinhibition and its impact on measurements of seasonal changes in water column productivity. There seems little doubt, however, that had we based our estimates of productivity on single endpoint sampling from full day incubations, serious underestimates of surface productivity would have resulted in all but the summer experiments. What effect these underestimates would have had on measurements of integrated water column productivity in Vineyard Sound is difficult to ascertain because our studies were limited to several light levels $\geq 30 \% \mathrm{I}_{0}$. By comparison, there has been a clear trend for $\Sigma \mathrm{P}$ : TP integrated over the water column to be ca. 1.3 to 1.5 in the few studies in which back to back incubations have been carried out, and, as in our study (Table 4), to be as high as 2 to 3 for the surface and near surface (Table 6). Jewson and Wood (1975) do point out, however, that when the depth of the mixed layer is greater than that of the euphotic zone, real reductions in total water column productivity result which could offset the apparent underestimate due to surface photoinhibition, as determined from a bottle incubation.

One conclusion, which is well documented in our study and confirmed in other studies - e.g. Rodhe (1958), Vollenweider and Nauwerck (1961) - is that the 'mid-day suppression' in primary production we observed was, to a large extent, an incubation artifact. To illustrate this point, consider that had only a single full-day incubation been employed during May and September, we would have drawn the mistaken conclusion that $>50 \%$ of the total daily production had occurred during the first $3 \mathrm{~h}$ of the day (Table 4). Use of back to back $3 \mathrm{~h}$ incubations, by raising the total daily production, reduced those early morning contributions to $\leq 35 \%$; but, as seen by our estimates of $\Sigma \mathrm{P}^{\prime}$ : TP (Table 4), even $3 \mathrm{~h}$ incubations may have been too long in our case to minimize the effects of photoinhibition.

Table 6. Comparison of primary productivity estimates based on summed short-term ( $\sum$ P) and full day, single end-point measurement (TP) from reported studies involving ${ }^{14} \mathrm{C}$ bottle incubations

\begin{tabular}{|c|c|c|c|c|c|c|c|}
\hline Water body & $\begin{array}{c}\text { Date } \\
\text { of study }\end{array}$ & $\begin{array}{c}\text { Total in- } \\
\text { cubation } \\
\text { duration (h) }\end{array}$ & $\begin{array}{l}\text { Incubation } \\
\text { interval } \\
\text { (h) }\end{array}$ & $\% I_{0}$ & $\Sigma P: T P$ & $\begin{array}{l}\text { Integrated } \\
\Sigma P: T P^{*}\end{array}$ & Source \\
\hline \multirow{3}{*}{$\begin{array}{l}\text { Lake Erken, } \\
\text { Sweden } \\
\text { (Freshwater) }\end{array}$} & 17 May 1956 & 19.0 & $3-4$ & $30-80$ & $1.3-2.9$ & 1.3 & \multirow{3}{*}{$\begin{array}{l}\text { Rodhe (1958) } \\
\text { Vollenweider and } \\
\text { Nauwerck (1961) }\end{array}$} \\
\hline & 30 May 1956 & 20.0 & 4 & $30-55$ & $1.3-1.4$ & 1.3 & \\
\hline & $1 \mathrm{Jul} 1956$ & 18.0 & $3-4$ & $45-70$ & $1.5-2.1$ & 1.3 & \\
\hline Lake Werowrap, & 2 Mar 1970 & 13.5 & $4-5$ & - & - & 1.2 & \multirow{4}{*}{$\begin{array}{l}\text { Hammer et al. } \\
\text { (1973) }\end{array}$} \\
\hline Australia & 23 Aug 1970 & 10.5 & 3.5 & - & - & 1.5 & \\
\hline (Freshwater) & 17 Sep 1970 & 12.0 & $3.5-5$ & - & - & 1.6 & \\
\hline & 26 Sep 1970 & 12.5 & $3.5-5$ & - & - & 1.3 & \\
\hline $\begin{array}{l}\text { North Equatorial } \\
\text { Current (Marine) }\end{array}$ & 30 Nov 1978 & 14.0 & 2 & 30 & 2.8 & - & $\begin{array}{l}\text { Gieskes et al. } \\
(1979)\end{array}$ \\
\hline $\begin{array}{l}\text { Kaneohe Bay } \\
\text { Hawail (Marine) }\end{array}$ & 13 Nov 1976 & 12.0 & 1 & $\cdots$ & 1.0 & - & $\begin{array}{l}\text { Redalje and } \\
\text { Laws (1981) }\end{array}$ \\
\hline
\end{tabular}


The choice between 'long' and 'short' incubations has been a continuing dilemna for phytoplankton ecologists. On the one hand, advocates for incubations lasting for 4 to $24 \mathrm{~h}$ have argued that such durations are a necessary prerequisite for establishing ${ }^{14} \mathrm{C}$ isotopic equilibrium so that net primary production is measured (Eppley and Sharp, 1975; Hobson et al., 1976; Marra et al., 1981). Li and Harrison (1982), in fact, have shown that even $24 \mathrm{~h}$ incubations do not guarantee the attainment of isotopic equilibrium. On the other hand, various problems with confinement in bottles have led others to promote the use of short (up to several h) incubations, even though this technique is limited to measurement of gross productivity (Harris and Piccinin, 1977; Venrick et al., 1977; Goldman et al., 1981).

From our own results, and from those summarized in Table 6, we conclude that the choice of incubation period cannot be established without considerable knowledge of the physics and biology of the water mass in question. Clearly, many factors are involved in this choice. Well-mixed coastal and upwelled phytoplankton may, as a general rule, be the most likely to exhibit unrepresentative photoinhibition during long confinement in bottles. Seasonal variations in this type of response for a given water body complicate tremendously the choice of incubation duration. Our own preference is to perform back to back incubations that span the entire day, with each incubation, not only involving time-course measurements, but continuing until sunset. Such an approach provides the greatest flexibility for data interpretation when trying to sort out artifacts of confinement in bottles from real water column effects. However, when integrated water column measurements of primary productivity are required, the increasing number of time-course incubations that are required as the day progresses probably negates the utility of this approach. The protocols adapted by Rodhe (1958) and Vollenweider and Nauwerck (1961), which are similar to those suggested above, but without time-course measurements, seem to be a reasonable trade-off.

Acknowledgements. This study was supported by Grant No OCE-B024445 from the National Science Foundation. We thank Dr. Edward J. Carpenter for cell counts and species identifications and Carol B. Riley for her able technical assistance.

\section{LITERATURE CITED}

Barnett, A. M., Hirota, J. (1967). Changes in the apparent rate of ${ }^{14} \mathrm{C}$ uptake with length of incubation period in natural phytoplankton populations. Limnol. Oceanogr. 12: 349-353

Belay, A. (1981). An experimental investigation of inhibition of phytoplankton photosynthesis at lake surfaces. New Phyytol. 89: 61-74
Brand, L. E., Guillard, R. R. L. (1981). The effects of continuous light and light intensity on the reproduction rates of twenty-two species of marine phytoplankton. J. exp. mar Biol. Ecol. 50: 119-132

Bumpus, D. F., Wright, W. R., Vaccaro, R. F. (1971). Sewage disposal in Falmouth, Massachusetts. II. Predicted effect on the proposed outfall. J. Boston Soc. Civil Engrs. 58: 255-277

Cloern, J. E. (1977). Effects of light intensity and temperature on Cryptomonas ovata (Cryptophyceae) growth and nutrient uptake rates. J. Phycol. 13: 389-395

Eppley, R. W., Sharp, J. H. (1975). Photosynthetic measurements in the Central North Pacific: the loss of carbon in 24-hour incubations. Limnol. Oceanogr. 20: 981-987

Faust, M. A., Gantt, E. (1973). Effect of light intensity and glycerol on the growth, pigment composition, and ultrastructure of Chroomonas sp. J. Phycol. 9: 489-495

Gallegos, C. L., Hornberger, G. M., Kelly, M. G. (1980). Photosynthesis-light relationships of a mixed culture of phytoplankton in fluctuating light. Limnol. Oceanogr. 25: 1082-1092

Gallegos, C. L., Platt, T. (1982). Phytoplankton production and water motion in surface mixed layers. Deep Sea Res. 29: $65-76$

Gieskes, W. W. C., Kraay, G. W., Baars, M. A. (1979). Current ${ }^{14} \mathrm{C}$ methods for measuring primary production: gross underestimates in oceanic waters. Neth. J. Sea Res. 13: $58-78$

Glibert, P. M., Goldman, J. C., Carpenter, E. J. (1982). Seasonal variations in the utilization of ammonium and nitrate by phytoplankton in Vineyard Sound, Massachusetts, USA. Mar. Biol. 70: 237-249

Goldman, J. C. (1979). Bioengineering aspects of inorganic carbon supply to mass algal cultures. In: Proceedings Third Annual Biomass Energy Sytems Conference. Rep. SERI/TP-33-285, Solar Energy Research Institute, Golden, Colorado, p. 25-32

Goldman, J. C., Taylor, C. D., Glibert, P. M. (1981). Nonlinear time-course uptake of carbon and ammonium by marine phytoplankton. Mar. Ecol. Prog. Ser. 6: 137-148

Goodwin, T. W. (1974). Carotenoids and biliproteins. In: Stewart, W. D. P. (ed.) Algal physiology and biochemistry. University of California Press, Berkeley, p. 176-203

Hammer, U. T., Walker, K. F., Williams, W. D. (1973). Derivation of daily phytoplankton production estimates from short-term experiments in some shallow, eutrophic Australian saline lakes. Aust. J. mar. Freshwat. Res. 24: 259-266

Harris, G. P. (1978). Photosynthesis, productivity and growth. The physiological ecology of phytoplankton. Ergebn. Limnol. 10: 1-171

Harris, G. P. (1980). The measurement of photosynthesis in natural populations of phytoplankton. In: Morris, I. (ed.) The physiological ecology of phytoplankton. University of California Press, Berkeley, p. 129-187

Harris, G. P., Lott, J. N. A. (1973). Light intensity and photosynthetic rates in phytoplankton. J. Fish. Res. Bd Can. 30: 1771-1778

Harris, G. P., Piccinin, B. B. (1977). Photosynthesis by natural phytoplankton populations. Arch. Hydrobiol. 80: 405-457

Hobson, L. A., Hartley, F. A. (1983). Ultraviolet irradiance and primary production in a Vancouver Island fjord, British Columbia, Canada. J. Plankton Res. 5: 325-331

Hobson, L. A., Morris, W. J., Pirquet, K. T. (1976). Theoretical and experimental analysis of the ${ }^{14} \mathrm{C}$ technique and its use in studies of primary production. J. Fish. Res. Bd Can. 33: 1715-1721 
Ichimura, S., Saijo, Y, (1958). On the application of ${ }^{14} \mathrm{C}$ method to measuring organic matter production in the lake. Bot. Mag. Tokyo 71: 174-180

Jewson, D. H., Wood, R. B. (1975). Some effect on integral photosynthesis of artificial circulation of phytoplankton through light gradients. Verh. int. Verein. theor. Limnol. 19: $1037-1044$

Jones, R. I. (1978). Adaptations to fluctuating irradiance by natural phytoplankton communities. Limnol. Oceanogr. 23: 920-926

Kok, B. (1956). On the inhibition of photosynthesis by intense light. Biochim. biophys. Acta 21: 234-244

Li, W. K. W., Harrison, W. G. (1982). Carbon flow into the endproducts of photosynthesis in short and long incubations of a natural phytoplankton population. Mar. Biol. 72: 175-182

Lund, J. W. G., Kilpling, C., LeCren, E. D. (1958). The inverted microscope method of estimating algal numbers and the statistical basis of estimation by counting. Hydrobiologia 11: $143-170$

Marra, J. (1978a). Effect of short-term variations in light intensity on photosynthesis of a marine phytoplankton. A laboratory simulation study. Mar. Biol. 46: 191-202

Marra, J. (1978b). Phytoplankton photosynthetic response to vertical movement in a mixed layer. Mar. Biol. 46: 203-208

Marra, J., Landrian G., Ducklow, H. W. (1981). Tracer kinetics and plankton rate processes in oligotrophic oceans. Mar Biol. Lett. 2: 215-223

Morgan, K. C., Kalff, J. (1979). Effect of light and temperature interactions on growth of Cryptomonas erosa (Cryptophyceae). J. Phycol. 15: 127-134

Myers, J., Burr, G. O. (1940). Studies on photosynthesis. Some effects of light of high intensity on Chlorella. J. gen. Physiol. 24: 45-67
Platt, T., Gallegos, C. L., Harrison, W. G. (1980). Photoinhibition of photosynthesis in natural assemblages of marine phytoplankton. J. mar. Res. 38; 687-701

Redalje, D. G., Laws, E. A. (1981). A new method for estimating phytoplankton growth rates and carbon biomass. Mar Biol. 62: 73-79

Richardson, K., Beardall, J., Raven, J. A. (1983). Adaptation of unicellular algae to irradiance: an analysis of strategies. New Phytol. 93: 157-191

Rodhe, W. (1958). The primary production of lakes: some results and restrictions of the ${ }^{14} \mathrm{C}$ method. Rapp. Cons. Explor. Mer 144: 122-128

Savidge, G. (1980). Photosynthesis of marine phytoplankton in fluctuating light regimes. Mar. Biol. Lett. 1: 295-300

Schindler, D. W., Holmgren, S. K. (1971). Primary production and phytoplankton in the experimental lakes area, Northwestern Ontario and other low carbonate waters, and a liquid scintillation method for determining ${ }^{14} \mathrm{C}$ activity in photosynthesis. J. Fish. Res. Bd Can. 28: 189-201

Sorokin, C. (1960). Injury and recovery of photosynthesis in cells of successive developmental stages. The effect of light intensity. Physiologia Pl. 13: 687-700

Takahashi, M., Shimura, S., Vamaguchi, Y., Fujita, Y. (1971). Photo-inhibition of phytoplankton photosynthesis as a function of exposure time. J. Oceanogr. Soc. Japan 2: 43-50

Venrick, E. L., Beers, J. R., Heinbokel, J. F. (1977). Possible consequences of containing microplankton for physiological rate measurements. J. exp. mar. Biol. Ecol. 26: 55-76

Vollenweider, R. A., Nauwerck, A. (1961). Some observations on the C14 method for measuring primary production. Verh. internat. Verein. Limnol. 14: 134-139

Yoder, J. A. (1979). Effect of temperature on light-limited growth and chemical composition of Skeletonema costatum (Bacillariophyceae). J. Phycol. 15: 362-370 